\title{
PENINGKATAN PENGETAHUAN DAN KETERAMPILAN SADARI PADA IBU USIA REPRODUKSI DI LEBAK BANDUNG TAHUN 2017
}

\author{
Gustina $^{1)}$, Nurbaiti ${ }^{2)}$ \\ ${ }^{1) 2}$ Program Studi D III kebidanan STIKes Baiturrahim Jambi \\ Email: Gtina1870@gmail.com
}

\begin{abstract}
ABSRACK
Breast cancer is cancer that forms in the breast tissue. breast cancer malignancy in Indonesia. One of the ways to reduce the possibility of developing breast cancer is by stitching the breast self examination (BSE). The role of biadan can provide counseling and counseling to the public about BSE health.The community service was carried out aimed at increasing the knowledge and skills of BSE in reproductive age mothers in Bandung. This service was carried out on June 8, 2017. The community service implementation team was carried out by STIKBA lecturers about self breast examination (BSE). Dilebak bandung.
\end{abstract}

Keywords:Knowledge, skills, breast self-examination

\begin{abstract}
ABSTRAK
Kanker payudara adalah kanker yang terbentuk di jaringan payudara. Keganasan kanker payudara di Indonesia menempati urutan ke dua pada wanita setelah kanker serviks. Salah satu untuk mengurangi kemungkinan berkembangnya kanker payudara yaitu dengan cara kesadaran akan pemeriksaan payudara sendiri (SADARI). Peran bidan yaitu dapat memberikan penyuluhan dan konsling kesehatan kepada masyarakat tentang SADARI. Pengabdian kepada masyarakat ini dilaksanakan bertujuan untuk meningkatkan pengetahuan dan ketrampilan SADARI pada ibu usia reproduksi di Lebak Bandung dan ini dilaksanakan pada bulan Juni 2017. Tim pelaksanaan pengabdian masyarakat yang dilakukan oleh dosen STIKBA tetang pemeriksaan payudara sendiri (SADARI) di Lebak Bandung.
\end{abstract}

Kata kunci: Pengetahuan, keterampilan, pemeriksaan payudara sendiri

\section{PENDAHULUAN}

Diperkirakan setiap tahun, 12 juta orang di seluruh dunia menderita kanker dan 7,6 juta di antaranya meninggal dunia. Jika tidak dikendalikan, diperkirakan 26 juta orang akan menderita kanker dan 17 juta meninggal karena kanker pada tahun 2030. Kejadian ini akan terjadi lebih cepat di negara miskin dan berkembang (International Union Againt cancer/UICC, 2000). Menurut WHO 8-9\% wanita di dunia mengalami kanker payudara. Ini menjadikan kanker payudara sebagai jenis kanker yang paling banyak ditemui pada wanita dan tahun 2000 diperkirakan 1,2 juta wanita terdiagnosis kanker payudara dan lebih dari 700,000 meninggal karenanya. Saat ini, kanker payudara memiliki peringkat 5\% - 10\% dari seluruh jenis kanker dan kanker payudara menduduki ranking pertamadiantara kanker lainnya pada wanita. Kanker payudara merupakan 
penyebab utama kematian pada wanita akibat kanker (Hompendin, 2000).

Menurut data WHO, negara industri memiliki penduduk dengan penyakit kanker yang besar dengan rasio sudah mencapai 100 : 100.000 penduduk positif kanker payudara. Jadi, 1 dibanding 1.000. Menurut dr Sutjipto Sp (B)Onk, Ketua Yayasan Kesehatan Payudara Jakarta (YKPJ) dalam abad penyakit kanker (cancerous age), di negara berkembang bebannya jadi ganda. Secara perlahan tetapi pasti, jumlah penderita kanker di negara Indonesia makin banyak, karena negara kita perlahan-lahan menjadi sebuah negara industri(Kompas, 2011).

Kanker sendiri menjadi penyebab kematian kelima. Keganasan kanker payudara di Indonesia menempati urutan kedua pada wanita setelah kanker leher rahim pada penelitian pathological-based, dengan frekuensi relatif $15,83 \%$ sesudah kanker leher rahim $(25,57 \%)$, walaupun di beberapa rumah sakit besar telah terlihat bahwa frekuensi relatif kanker payudara lebih tinggi dibanding kanker rahim(Aryandono, 2005). Hingga kini, belum diketahui penyebab utama timbulnya penyakit ini. Bahkan, wanita usia muda juga mulai terancam (Viva news, 2010).

Kanker payudara adalah kanker yang terbentuk di jaringan payudara, biasanya saluran (tabung yang membawa susu ke puting) dan lobulus kelenjar yang membuat susu). Hal ini terjadi baik pada pria maupun wanita meskipun kanker payudara pada pria jarang terjadi. Belum diketahui penyebab langsung dari kanker payudara, tetapi ada beberapa faktor resiko yang membuat wanita terkena kanker payudara yaitu : keluarga yang memiliki riwayat penyakit kanker, usia yang semangkin bertambah, sejarah pribadi kesehatan,beberapa Perubahan tertentu gen, seperti BRCA1 atau BRCA2, secara substansial meningkatkan risiko kanker payudara, wanita yang pertama kali menstruasi sebelum usia 12 tahun berada pada peningkatan risiko kanker payudara, wanita yang mengalami SADARI setelah usia 55 berada pada peningkatan risiko kanker payudara, wanita yang mengambil terapi hormon SADARI selama bertahuntahun memiliki. Peningkatan risiko kanker payudara, wanita yang sering minum alkhohol semangkin besar resiko terkena kanker payudara ( National Cancer Institut, 2010).

Faktor genetik hanya berdampak 5$10 \%$ dari terjadinya kanker payudara dan ini menunjukkan bahwa faktor resiko lainnya memainkan peranan penting. Pentingnya faktor usia sebagai faktor resiko diperkuat oleh data bahwa $78 \%$ kanker payudara terjadi pada pasien yang berusia lebih dari 50 tahun dan hanya 6\% pada pasien yang kurang dari 40 tahun. Rata-rata usia pada saat ditemukannya kanker adalah 64 tahun. Studi juga mengevaluasi peranan faktor gaya hidup dalam perkembangan kanker payudara yang meliputi pestisida, konsumsi alkohol, kegemukan, asupan lemak serta kurangnya olah fisik. Sejumlah studi memperlihatkan bahwa deteksi kanker payudara dan serta terapi dini dapat meningkatkan harapan hidup dan memberikan pilihan terapi lebih banyak pada pasien.Terbukti 95\% wanita yang terdiagnosis pada tahap awal kanker payudara dapat bertahan hidup lebih dari lima tahun,angka umur harapan hidup yang meningkat setelah terdiagnosisdini pada kanker payudara membuat banyak dokter merekomendasikan agar para wanita menjalani 'SADARI' (periksa payudara sendiri) pada saat menstruasi di rumah secara rutin dan menyarankan dilakukannya pemeriksaan rutin tahunan untuk mendeteksi benjolan pada payudara. Pada umumnya, kanker payudara dideteksi oleh penderita sendiri dan biasanya berupa benjolan yang keras dan kecil (Hompedin,2010).

Karena masih tinginya kejadian kanker payudara maka perlu memberikan penyuluhan dan keterampilan SADARI 
pada ibu usia reproduksi di Lebak Bandung agar pengetahuan dan keterampilan SADARI pada ibu usia reproduksi meningkat dan ibu ibb bisa melakkan pemeriksaan sendiri.

Pemeriksaan payudara sendiri (SADARI) adalah suatu prosedur untuk mengetahui kelainan-kelainan pada payudara dengan melakukan inspeksi secara berkala.

Tujuan melakukan SADARI adalah untuk mendeteksi adanya kelainan-kelainan pada payudara baik struktur, bentuk atau tekstur, SADARI dilakukan setiap wanita yang telah mengalami siklus menstruasi dan wanita yang telah mengakhiri siklus menstruasi (menopause). SADARI dilakukan setiap bulan selama kurang 5 menit antara hari kelima dan kesepuluh pada siklus menstruasi dengan menghitung hari pertama menstruasi sebagai hari pertama. SADARI dapat juga langsung dilakukan apabila dicurigai adanya kelainan pada payudara (Hijrah, 2010).

Gejala yang diamati pada SADARI umumnya adalah, benjolan yang tidak hilang atau permanen, biasanya tidak sakit dan terasa keras bila disentuh atau penebalan pada kulit payudara atau di sekitar ketiak, perubahan ukuran pada bentuk payudara, keluarnya cairan dari payudara umumnya berupa darah, kerutan pada kulit payudara, pembengkakan atau tarikan pada puting susu (Annia Kissanti, 2007:55).

Untuk mencegah dan mewaspadai kanker payudara wanita dapat melakukan hal-hal sebagai berikut :1). Pada wanita produktif, SADARI harus dilakukan sebulan sekali, 4-5 hari setelah haid. 2). Bagi perempuan yang telah mengalami menopause SADARI dapat dilakukan kapanpun setiap bulan 3). Bagi wanita di atas 40-50 tahun dianjurkan memeriksakan diri / check up rutin pada dokter (Luw, 2003).

Sebaiknya dilakukan seminggu sesudah menstruasi, ketika kondisi payudara lunak dan longgar, sehingga memudahkan perabaan. Untuk wanita yang sudah mengalami menopause, dapat dilakukan kapan saja, akan lebih baik jika setiap kali melakukan SADARI disiapkan buku khusus untuk mencatat hasil pemeriksaan juga kondisi dan perubahan yang terjadi pada payudara, juga kondisi dan perubahan payudara dari waktu ke waktu. Bila perlu lengkapi dengan gambar ilustrasi untuk memperjelas lokasi kelainan yang ditemukan.

Prosedur SADARI menurut Yayasan Kanker Indonesia (2003) yaitu :

Langkah I. Perhatikan dengan teliti payudara kita didepan cermin, tanpa berpakaian, dengan kedua tangan urus kebawah. Perhatikan bila ada benjolan atau perubahan bentuk pada payudara. Amati dengan teliti, sebab kita sendirilah yang lebih mengenal tubuh kita. Angkatlah kedua lengan ke atas dan ulangi pemeriksaan seperti diatas. Langkah 2 . Kedua siku mengarah kesamping, tekanlah telapak tangan yang satu kuat-kuat pada yang lain. Cara ini akan menegangkan otot dada dan perubahan-perubahan seperti cekungan dan benjolan akan lebih kelihatan.. Langkah 3.Lakukan pada kedua payudara, pencetlah pelan-pelan di daerah sekitar puting dan amatilah apakah keluar cairan yang tidak normal (tidak biasa)..Langkah 4.Bebaringlah kemudian tangan kanan di bawah kepala, letakkan bantal kecil di bagian punggung kanan dan rabalah seluruh permukaan payudara kanan dengan gerakan seperti diuraikan pada langkah .Langkah 5.Meraba dengan tiga jari tengah yang dirapatkan kemudian lakukan gerakan memutar denga tekanan lebut tetapI mantap dimulai dari pinggir dengan mengikuti arah putaran jarum jam. Langkah 6. Melakukan yang sama seperti langkah nomor 4, tetapi dengan tangan kiri dibawah kepala sedang tangan kanan meraba payudara kiri. Langkah 7. Memberikan perhatian khusus pada bagian-bagian payudara yaitu bagian payudara sebelah 
kanan dan kiri, sebab di daerah tersebut yang sering ditemukan tumor payudara.

Faktor yang menyebabkan keterlambatan pengobatan dan pencegahan kanker payudara di Indonesia adalah : 1). Takut operasi, kemoterapi dan radiasi 2). Masih percaya, dengan pengobatan tradisional, dukun, paranormal 3). Tidak percaya kanker payudara bisa disembuhkan 4). Tidak menyadari penyakit yang dideritanya 5).Tidak mengetahui perlu check up payudara secara rutin

\section{TARGET DAN LUARAN}

Ibu-ibu memperoleh informasi yang tepat mengenai kesehatan dan memahami serta dapat melaksanakan dalam kehidupan sehari-hari dan meningkatkan pengetahuan dan ketrampilan SADARI pada ibu usia reproduksi di Lebak Bandung.

\section{METODE PELAKSANAAN}

Sasaran pengabdian kepada masyarakat ini adalah ibu-ibu usia reproduksi dengan metode ceramah, tanya jawab demostrasi dan praktek, menggunakan media leptop, leflet, LCD, Job sheet. Waktu pelaksanan yaitu pada bulan Juni 2017 di PUSTU Kel. Lebak Bandung.

\section{HASIL PEMBAHASAN}

Hasil dari pengabdian masyarakat di kelurahan Lebak Bandung :

1. Pengetahuan ibu-ibu yang di Lebak Badung meningkat dari yang tidak tahu menjadi tahu tentang pemeriksaan SADARI sebagai deteksi dini pada kanker payudara.

2. Ibu -ibu dapat melakukan deteksi dini adanya kelainan pada payudara dengan cara melakukan SADARI secara kontinyu.
3. Ibu - ibu yang mempunyai anak remaja putri juga dapat mengajarkan SADARI dan dapat melakukannya.

4. Ibu - ibu dapat berbagi dengan ibu-ibu yang berada di lingkungan tempat ibu tinggal

Dengan dilaksanakannya pengabdian pada masyarakat bahwa semakin dini ibuibu menemukan gejala dari kanker payudara maka pengobatan dan tindakan akan segera dapat dilakukan sedini mungkin

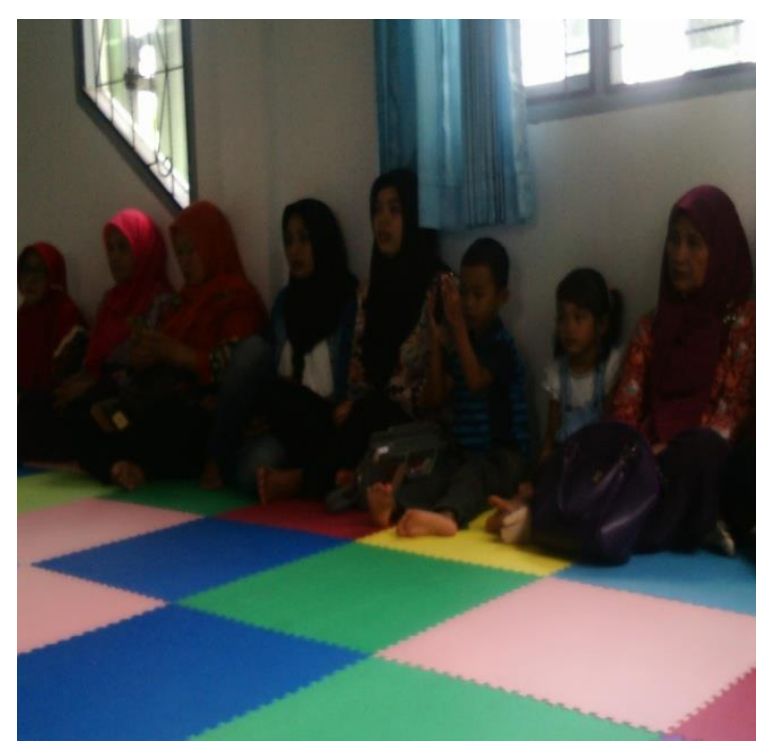

Gambar 1 Penyuluhan sadari

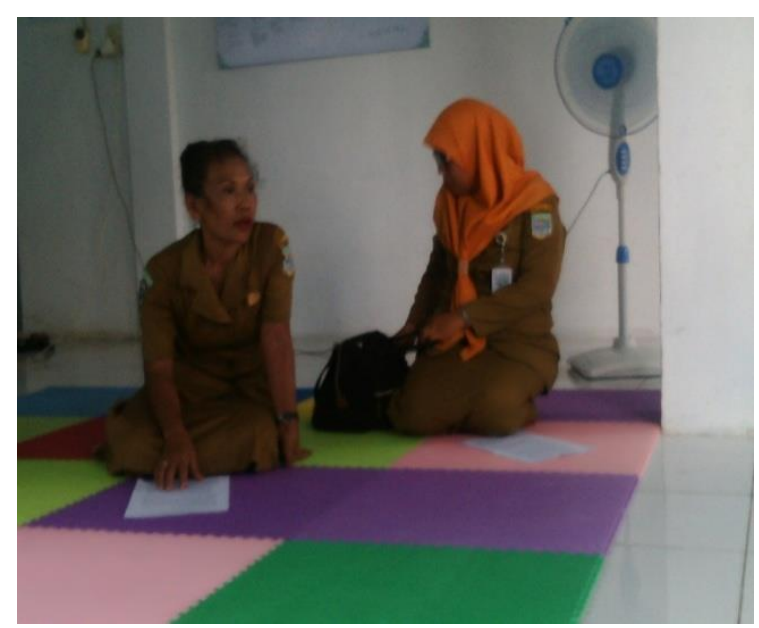

Gambar 2 Tim Pengabmas 


\section{KESIMPULAN DAN SARAN}

\section{Kesimpulan}

Pelaksanaan pengabdian masyarakat yang dilakukan oleh dosen STIKBA tentang pemeriksaan payudara sendiri (SADARI) di Lebak Bandung berjalan dengan lancar. Di harapkan agar ibu-ibu mengetahui dan melakukan pemeriksaan payudara sendiri untuk mendeteksi kanker payudara.

\section{Saran}

Kepada Instansi yang terkait disarankan agar melakukan kegiatan penyuluhan secara rutin sehingga ibu-ibu lebih mengetahui dan mau melakukan pemeriksaan payudara sendiri untuk mendeteksi kanker payudara.

\section{UCAPAN TERIMAKASIH}

Tim pengabmas mengucapkan terimaksih yang sebesar-besarnya kepada STIKes Baiturrahim Jambi, berupa dana, fasilitas surat izin dan ibu-ibu yang berada di Kel Lebak Bandung, RT, RW dan kelurahan yang telah memberikan izin tempat pengabdian masyarakat sehingga kegiatan pengabdian masyarakat ini dapat berjalan dengan lancar sesuai dengan waktu yang di tentukan.

\section{DAFTAR PUSTAKA}

Anonim, http://creasoft.wordpress.com/2009/0 4/19/periksa-payudara-sendirisadarisararil

Anonim,http://www.dechacare.com/Kanker -Payudara-Pengertian-danPenyembuhan-I319. html diunduh tanggal1 November 2010

Anonim, http://www.hompedin.org/download/ kanker payudara. pdf diunduh tanggal 1 November 2010

Soekidjo.2007. Promosi Kesehatan dan Ilmu Perilaku Kesehatan. Jakarta: RinekaCipta

Sutjipto,http://djaygoblog.blogspot.com/20 10/01/penyuluhan-kesehatan.html, Diunduh tanggal 20 Desember 2010

http://kompas.com/news/read/185192-agarterhindar-kanker-payudara diunduh tanggal 11 November 2010

Fitria, Ana. 2007. Panduan Lengkap Kesehatan Wanita. Jakarta :Gala IlmuSemesta

John R.LEE, M.D, 2008. Kanker Payudara Pencegahan Dan Pengobatannya, Jakarta: Gala Semesta.

De Jong, 2005. Kanker Payudara, Jakarta : Multi Media

Kisanti, Annia. 2007. Buku Pintar Wanita, Jakarta :Araska.

Pita pink, 2006, Pita Pink Peduli Kanker Payudara RS. Kanker "Darmais",Jakarta. http://www.pitapink.com/id/pr190920 $\underline{05-2}$

Luwia, 2003, Problemati perawatan Payudara, Cetakan Pertama, Kawan Pustaka, Jakarta.

Dixon, Michael M.J.R.dk, 2002, Kelainan Payudara, Penerbit Dian Rakyat, Jakarta 